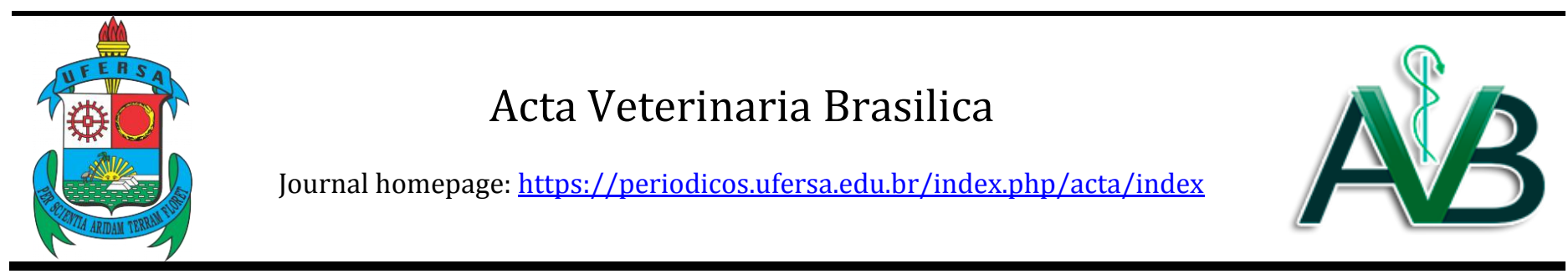

Original Article

\title{
Cassava foliage in quail feeding
}

\author{
Paulo Antonio Silva Júnior ${ }^{1}$, Sandra Roseli Valerio Lana ${ }^{2 *}$, Geraldo Roberto Quintão Lana², Luis Carlos Lira \\ Silva2 $^{2}$, Elisama Castro Torres², Thamires Silva Ferreira²
}

1 Universidade Federal da Paraíba. Centro de Ciências Agrárias. CCA-UFPB, Campus Areia, Areia - PB. Brasil.

2 Universidade Federal de Alagoas. Centro de Ciências Agrárias. CECA-UFAL. Maceió - AL., Brasil.

\section{A R T I C L E I N F O}

\begin{tabular}{l}
\hline Article history \\
Received 21 March 2017 \\
Received in revised form 09 June 2017 \\
Accepted 15 June 2017 \\
\hline Keywords: \\
Quail farming \\
Manihot esculenta \\
Agricultural by-product \\
\end{tabular}

\section{INTRODUCTION}

Quail farming stands out as the fastest growing poultry segment, with an increasing participation in the industrial scenario of meat and egg production. However, feed costs are the most expensive item in the poultry production chain, which means that replacing corn and soybean - the most costly ingredients - in the diet fully or partially is a necessary measure.

Agricultural by-products and wastes have shown to be possible substitutes for these feedstuffs. A noteworthy example of such alternatives are cassava by-products (foliage, bark and inner bark, waste flour, among others), which are high sources of energy, protein, and minerals (CENI et al., 2009; GUEDES et al., 2007; SOUZA et al., 2011).

The cassava foliage, or upper third of the plant, is an agricultural by-product often wasted during the harvesting of the roots. This part includes the leaves, which are protein sources with a good essential and nonessential amino acid profile, according to Miranda et al. (2008). In terms of energy value, Cunha et al. (2009) obtained 1,523.98 kcal/kg AME and 1,448.28 kcal/kg AMEn for Japanese quail. Similarly, Silva; Fonseca; Guedes Filho (2000) found 1,697.00 kcal/kg AME in the hay of cassava foliage for broilers and Arruda et al. (2012) reported $1,732.76 \mathrm{kcal} / \mathrm{kg}$ AME from this ingredient for free-range broilers.

Cunha et al. (2009) and Silva et al. (2012) evaluated the inclusion of cassava foliage in Japanese quail diets and reported that the use of this by-product did not interfere with the performance of poultry in the growth, finishing, and laying phases, suggesting the use of up to $12 \%$ of the ingredient in their diet. These findings corroborate Iheukwumere et al. (2007), who stated that inclusion of up to $5 \%$ of cassava leaf hay did not compromise the performance or carcass yield of broilers.

\footnotetext{
*Corresponding author: sandraroselilana@gmail.com
} 
The cassava foliage can thus represent an important alternative feedstuff in poultry production. For this reason, research studies on the effects of this by-product in quail feeding are of paramount importance so that it can be indicated as an effective substitute for ingredients traditionally used as energy and protein sources in diets.

Given the above-stated considerations, this study was conducted to evaluate the effect of inclusion cassava foliage hay in quail diets on the performance, carcass characteristics, and economic viability of rearing this animals in the period of 1 to 35 days of age.

\section{MATERIAL AND METHODS}

Experimental procedures were approved by the Ethics Committee of Animal Experimentation (CEUA), under no. 0006555/2011-77.

The experiment was conducted at the Quail Farming Unit, Center for Agricultural Sciences, at UFAL, involving 400 one-day-old unsexed quail from the Fujikura quail farm, in Suzano - SP, Brazil, with an average initial weight of $9.35 \mathrm{~g}$. The quail were distributed into five treatments (CFH inclusion levels: 0.0, 5.0, 10.0, 15.0, and $20.0 \%$ ) in a completely randomized design with eight replicates and 10 birds per experimental unit, housed in galvanized-wire cages in a battery system inside a masonry shed equipped with a heat source, nipple drinkers, trough drinkers, and feces collection trays. A continuous lighting program of $24 \mathrm{~h}$ of natural + artificial light per day was adopted; the artificial light was provided by $40-\mathrm{W}$ incandescent bulbs. Climatic variables were monitored in the morning and afternoon.

Temperature and relative humidity were monitored using a digital thermo-hygrometer that was placed at the height of the cages, with readings performed daily at $08 \mathrm{~h} 00$ and $16 \mathrm{~h} 00$. Mean values for climatic variables were: maximum temperature: $27.65{ }^{\circ} \mathrm{C}$, minimum temperature: $26.25{ }^{\circ} \mathrm{C}$, relative humidity: $75.66 \%$, and black globe humidity index: 77.03 (calculated according to the formula proposed by Buffington et al. (1981)).

Experimental diets contained 2,800 kcal ME/kg and $26.00 \%$ crude protein (Table 1), following the recommendations of the NRC (1994). For the calcium requirements, the recommendations of Silva et al. (2011) were adopted, and for the inclusion of cassava foliage in the formulated diets, we considered the chemical and digestibility composition values described by Cunha et al. (2009).

In the preparation of the $\mathrm{CFH}$, we used the aerial foliar part of the plant, composed of the upper part of the stalk, leaves, and petioles. The harvested material was ground through a forage machine and dried in the sun and turned over every two hours, for two days, for volatilization of cyanogenic acid until reaching the point of hay. Afterwards, the by-product was placed in raffia bags and stored for four months in a location protected from moisture until the start of the experimental period. After this period, the hay was ground to be incorporated into the feed, following the experimental inclusion levels.

The following variables were evaluated: performance (feed intake, weight gain, and feed conversion), carcass characteristics (absolute and relative weights of carcass, cuts, and edible viscera), and economic analysis. To calculate the production-performance characteristics, we weighed the orts and the birds from each experimental unit separately.

At 35 days of age, two quails per experimental unit, weighing up to $5 \%$ of the average weight of the experimental unit, were identified, deprived of feed for six hours, and then slaughtered to determine their carcass yield. After manual plucking, their carcasses were eviscerated, washed, dripped, and weighed. The carcass yield was considered the weight of the clean carcass as a percentage of the fasted-bird live weight. Next, their cuts and viscera were removed. The yields of legs, breast, wings, back, and edible viscera were considered in relation to the weight of the eviscerated and clean carcass. For the economic analysis, we considered variations in live weight, feed intake, and costs of diets that occurred between the tested treatments; thus, the economic analysis was inherent to the production and feeding component, considering labor and other expenses of rearing equal birds for all treatments.

The CFH acquisition cost was estimated at $\mathrm{R} \$ 0.21 / \mathrm{kg}$, taking into account the costs of labor during harvesting, drying, and transport; the quail unit was considered $\mathrm{R} \$$ $8.95 / \mathrm{kg}$ (as of July 15, 2012). The live-quail sale price and the cost of the diet ingredients refer to the values adopted in the region during the experimental period.

The variables used in the economic analysis were gross revenue (GR) - total amount, in Brazilian reals (R\$) received as a function of live weight multiplied by the price of the bird; gross margin (GM) - the difference between the gross revenue and the feed cost); relative gross margin (RGM) - the quotient between the gross margin of the other by-product inclusion levels relative to the level of $0.0 \%$ (control diet); mean rate of return (MRR) - the quotient between the gross margin and the feeding cost, indicating the return on the investment in feed; and the relative return index (RRI) - the quotient between the mean rate of return of the several byproduct inclusion levels relative to the level of $0.0 \%$. The value of 100 was assigned to the relative margin and relative return index of the level of $0.0 \%$. The calculations pertaining to the economic viability evaluation were according to the methodology described by Lana (2000). 
Table 1. Centesimal and nutritional composition of experimental diets.

\begin{tabular}{|c|c|c|c|c|c|}
\hline \multirow[t]{2}{*}{ Ingredient } & \multicolumn{5}{|c|}{ CFH inclusion level (\%) } \\
\hline & 0.0 & 5.0 & 10.0 & 15.0 & 20.0 \\
\hline Corn & 49.2923 & 43.7540 & 38.2157 & 32.6774 & 27.1391 \\
\hline Soybean meal & 47.6254 & 46.5044 & 45.3834 & 44.2624 & 43.1414 \\
\hline Cassava hay & - & 5.0000 & 10.0000 & 15.0000 & 20.0000 \\
\hline Dicalcium phosphate & 1.3518 & 1.3872 & 1.4227 & 1.4582 & 1.4936 \\
\hline Limestone & 0.9051 & 0.8959 & 0.8867 & 0.8774 & 0.8682 \\
\hline Common salt & 0.2830 & 0.2851 & 0.2951 & 0.3011 & 0.3071 \\
\hline Vegetable oil & 0.2440 & 1.8555 & 3.4670 & 5.0785 & 6.6900 \\
\hline DL-methionine & 0.1483 & 0.1639 & 0.1794 & 0.1950 & 0.2106 \\
\hline Vitamin premix $^{1}$ & 0.1000 & 0.1000 & 0.1000 & 0.1000 & 0.1000 \\
\hline Mineral premix ${ }^{2}$ & 0.0500 & 0.0500 & 0.0500 & 0.0500 & 0.0500 \\
\hline TOTAL & 100.0000 & 100.0000 & 100.0000 & 100.0000 & 100.0000 \\
\hline \multicolumn{6}{|c|}{ 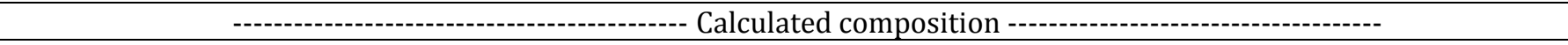 } \\
\hline $\mathrm{ME}(\mathrm{kcal} / \mathrm{kg})$ & 2.800 & 2.800 & 2.800 & 2.800 & 2.800 \\
\hline Crude protein $(\%)$ & 26.00 & 26.00 & 26.00 & 26.00 & 26.00 \\
\hline Calcium $(\%)$ & 0.850 & 0.850 & 0.850 & 0.850 & 0.850 \\
\hline Available P (\%) & 0.380 & 0.380 & 0.380 & 0.380 & 0.380 \\
\hline Sodium (\%) & 0.160 & 0.160 & 0.160 & 0.160 & 0.160 \\
\hline Crude fiber (\%) & 3.7810 & 4.8238 & 5.8669 & 6.9100 & 7.9532 \\
\hline Total methionine (\%) & 0.5402 & 0.5544 & 0.5686 & 0.5828 & 0.5970 \\
\hline Dig. methionine (\%) & 0.5070 & 0.5070 & 0.5070 & 0.5070 & 0.5070 \\
\hline Total met.+cys (\%) & 0.9340 & 0.9427 & 0.9514 & 0.9601 & 0.9688 \\
\hline Total lysine (\%) & 1.4472 & 1.4472 & 1.4472 & 1.4472 & 1.4472 \\
\hline Digestible lysine (\%) & 1.305 & 1.2654 & 1.2258 & 1.1862 & 1.1466 \\
\hline Total threonine (\%) & 1.010 & 1.0102 & 1.0099 & 1.0097 & 1.0095 \\
\hline Dig. threonine (\%) & 0.8830 & 0.8500 & 0.8172 & 0.7845 & 0.7517 \\
\hline Total tryptophan (\%) & 0.3391 & 0.3285 & 0.3179 & 0.3073 & 0.2967 \\
\hline Dig. tryptophan (\%) & 0.3066 & 0.2971 & 0.2876 & 0.2781 & 0.2686 \\
\hline
\end{tabular}

${ }^{1}$ Vitamin premix/kg: vit. A 13,440,000 IU; vit. D 3,200,000 IU vit. E 28,000 mg/kg; vit. K 2,880 mg/kg; thyamin 3,500 mg/kg; riboflavin 9,600 mg/kg; pyridoxin 5,000 mg/kg; cyanocobalamin 19,200 mcg/kg; folic acid 1,600 mg/kg; pantothenic acid 25,000 mg/kg; niacin $67,200 \mathrm{mg} / \mathrm{kg}$; biotin 80,000 mcg/kg; selenium $600 \mathrm{ppm}$; antioxidant $0.40 \mathrm{~g} / \mathrm{kg}$. ${ }^{2}$ Mineral premix/kg: Mg 150,000 ppm; Zn 140,000 ppm; Fe 100,000 ppm; Cu 16,000 ppm; I 1,500 ppm.

The obtained data were subjected to analysis of variance, and differences were analyzed by regression analysis at the $5 \%$ significance level, using the package $R$ (R Development Core Team, 2014).

\section{RESULTS AND DISCUSSION}

Feed intake and feed conversion in the period of 1 to 21 days of age responded linearly $(\mathrm{P}<0.05)$ to the cassava foliage hay inclusion levels (Table 2). Every $1 \%$ inclusion of the by-product led to a $1.11 \mathrm{~g}$ increase in feed intake and a reduction of 0.009 in feed conversion, according to the following equations:

$$
\begin{aligned}
& \hat{Y}=310,906+1,10607 X\left(R^{2}=0.80\right) \text { and } \\
& \hat{Y}=2,00025+0,00845000 X\left(R^{2}=0.84\right),
\end{aligned}
$$

respectively. No effect $(\mathrm{P}>0.05)$ of $\mathrm{CFH}$ levels were observed on weight gain. This finding can be explained by the limitation in fiber utilization and the gradual adaptation to the experimental diet in the initial life stage of the quail that resulted in an increased rate of passage and consequently reduced nutrient absorption, which caused the birds to increase their intake to offset and meet their nutritional requirements.

These results corroborate the studies of Costa et al. (2007), who observed an increase in feed intake by freerange chickens, although their weight gain and feed conversion were not influenced $(\mathrm{P}>0.05)$ by the dietary levels of cassava hay. Iheukwumere et al. (2007) and Silva et al. (2000), on the other hand, evaluated the inclusion of cassava foliage meal for chickens and observed a reduction in feed intake and weight gain, followed by a decrease in feed conversion. 
Table 2. Feed intake, weight gain, and feed conversion of quails from 01 to 21, 22 to 35, and 01 to 35 days of age fed diets with levels of cassava foliage hay.

\begin{tabular}{|c|c|c|c|c|c|c|}
\hline \multirow{3}{*}{ Parameter } & \multicolumn{6}{|c|}{ CFH inclusion level } \\
\hline & 0.0 & 5.0 & 10.0 & 15.0 & 20.0 & $\mathrm{CV}(\%)$ \\
\hline & \multicolumn{6}{|c|}{01 to 21 days of age } \\
\hline Feed intake (g/bird) ${ }^{\mathrm{L}}$ & 308.34 & 321.67 & 318.08 & 329.81 & 331.93 & 2.94 \\
\hline Weight gain (g/bird) ns & 154.62 & 155.77 & 155.22 & 153.19 & 153.47 & 2.43 \\
\hline \multirow[t]{2}{*}{ Feed conversion ${ }^{\mathrm{L}}$} & 1.99 & 2.06 & 2.05 & 2.15 & 2.16 & 2.46 \\
\hline & \multicolumn{6}{|c|}{22 to 35 days of age } \\
\hline Feed intake (g/bird) ${ }^{\mathrm{L}}$ & 453.36 & 456.32 & 453.23 & 483.05 & 488.89 & 3.87 \\
\hline Weight gain $(\mathrm{g} / \text { bird })^{\mathrm{L}}$ & 105.60 & 105.51 & 109.45 & 111.79 & 113.41 & 4.29 \\
\hline \multirow[t]{2}{*}{ Feed conversion ns } & 4.29 & 4.33 & 4.15 & 4.33 & 4.31 & 3.79 \\
\hline & \multicolumn{6}{|c|}{01 to 35 days of age } \\
\hline Feed intake (g/bird) ${ }^{\mathrm{L}}$ & 761.70 & 778.00 & 771.30 & 812.86 & 820.82 & 3.42 \\
\hline Weight gain (g/bird) L & 260.22 & 261.27 & 264.67 & 264.98 & 266.88 & 1.97 \\
\hline Feed conversion $\mathrm{L}$ & 2.93 & 2.98 & 2.92 & 3.07 & 3.08 & 2.94 \\
\hline
\end{tabular}

L Linear effect $(\mathrm{P}<0.05) ; \mathrm{Q}$ Quadratic effect $(\mathrm{P}<0.05) ;{ }^{\text {ns }}$ not significant $(\mathrm{P}<0.05)$.

In the period of 22 to 35 days of age, there was a linear increase $(\mathrm{P}<0.05)$ of $1.96 \mathrm{~g}$ in feed intake and $0.44 \mathrm{~g}$ in weight gain with every $1 \%$ of CFH included, according to the following respective equations:

$$
\begin{gathered}
\hat{Y}=447,410+1,95600 X\left(R^{2}=071\right) \text { and } \\
\hat{Y}=104,770+0,438175 X\left(R^{2}=0.92\right) .
\end{gathered}
$$

There was no significant effect $(P>0.05)$ of the tested by-product levels on the feed conversion of the quail. Despite the lack of effect of cassava foliage hay inclusion on this variable, the birds consuming the diet with $10 \%$ of the by-product showed the best feed conversion in absolute values (4.15). These results reveal a greater efficiency in fiber utilization by the birds in this period due to the better digestive and absorptive capacity of the digestive tract, especially in the ceca, which are already developed and adapted to the diet containing higher fiber contents. It is relevant to consider that the quail have a better utilization of the energy originating from fiber when compared with gallinaceous species, which is probably related to the larger relative size of the cecum.

Contrasting the present results, Trompiz et al. (2007) and Silva; Fonseca; Guedes Filho (2000) found a reduction in weight gain and feed conversion of chickens fed diets with levels of cassava leaves. Similarly, Eruvbetine et al. (2003) reported a sharp decrease in the feed intake and weight gain of broilers consuming diets including 10,20 , and $30 \%$ of cassava leaves and tuber.

Feed intake, weight gain, and feed conversion in the period of 1 to 35 days of age were influenced $(\mathrm{P}<0.05)$ linearly by the $\mathrm{CFH}$ inclusion levels. Feed intake and weight gain increased by $3.06 \mathrm{~g}$ and $0.34 \mathrm{~g}$, respectively, while feed conversion worsened by 0.008 with every $1 \%$ of addition of $\mathrm{CFH}$, as seen in the following respective equations:

$$
\begin{gathered}
\hat{Y}=758,315+3,06208 X\left(R^{2}=0.80\right), \\
\hat{Y}=260,195+0,340850 X\left(R^{2}=0.93\right), \text { and } \\
\hat{Y}=2,91500+0,00777500 X\left(R^{2}=0.55\right) .
\end{gathered}
$$

These results demonstrate a synergistic response of the $\mathrm{CFH}$ levels in the diet on the performance of the quail; the worse feed conversion was caused by the fact that the evaluated phase encompassed the first two weeks of life of the birds, which are characterized by lower utilization of high-fiber diets.

Similar results were obtained by Adeyemi ; Adekoya ; Sobayo et al. (2012), who evaluated the performance of broilers receiving diets containing cassava leaves and blood meal and found higher feed intake and weight gain and worse feed conversion in the animals receiving 50\% of the compound as compared with those fed the control treatment. By contrast, Furtado et al. (2011) observed a reduction in the feed intake, weight gain, and feed conversion in free-range broilers receiving diets with increasing levels of cassava hay. Likewise, Silva et al. (2012) did not observe an influence of inclusion of cassava shoots on the performance of Japanese quail, recommending the use of $12 \%$ of the by-product in quail diets.

The $\mathrm{CFH}$ inclusion levels $(\mathrm{P}<0.05)$ influenced the absolute weights of back, legs, and gizzard and the relative weights of breast, back, legs, and gizzard (Table $3)$. The absolute and relative weights of the carcass, other cuts, and edible viscera were not influenced $(\mathrm{P}>$ 0.05) by the CFH levels.

The absolute weight of the back increased quadratically $(\mathrm{P}<0.05)$ up to the $\mathrm{CFH}$ inclusion level of $18.45 \%$, in accordance with the following regression equation:

$$
\begin{aligned}
& \hat{Y}=49,2281+0,661718 X-0,0179321 X^{2} \\
& \left(R^{2}=0.97\right) \text {. }
\end{aligned}
$$


A linear effect was observed $(\mathrm{P}<0.05)$ on the relative weights of back, breast, and legs. The relative weight of the back increased by $0.13 \mathrm{~g} /$ bird, whereas the relative weights of breast and legs decreased by $0.09 \mathrm{~g}$ and 0.05 $\mathrm{g} / \mathrm{bird}$, respectively, with every $1 \%$ of inclusion of the by-product, as shown by the respective equations

$$
\begin{aligned}
\hat{Y}= & 26,4387+0,13285 X\left(R^{2}=0.94\right), \\
\hat{Y}= & 41,8115-0,0887750 X, \text { and } \hat{Y}= \\
& 23,2362-0,0479 X\left(R^{2}=0.79\right) .
\end{aligned}
$$

No effect $(\mathrm{P}>0.05)$ of the CFH inclusion levels was found on the absolute and relative weights of the other cuts.

\begin{tabular}{|c|c|c|c|c|c|c|}
\hline \multirow[b]{2}{*}{ Variable } & \multicolumn{6}{|c|}{ CFH inclusion level (\%) } \\
\hline & 0.0 & 5.0 & 10.0 & 15.0 & 20.0 & $\mathrm{CV}(\%)$ \\
\hline \multicolumn{7}{|c|}{ Absolute weight (g) } \\
\hline Slaughter weightns & 261.44 & 267.50 & 277.94 & 279.44 & 270.94 & 2.74 \\
\hline Carcass $^{\mathrm{ns}}$ & 188.85 & 187.64 & 195.99 & 194.09 & 190.24 & 1.85 \\
\hline Breastns $^{\mathrm{ns}}$ & 79.71 & 76.67 & 80.49 & 78.08 & 76.68 & 2.22 \\
\hline Back $^{Q}$ & 49.45 & 51.56 & 54.33 & 55.28 & 55.16 & 4.82 \\
\hline Legs $^{\text {ns }}$ & 43.70 & 43.53 & 44.21 & 43.86 & 42.33 & 1.66 \\
\hline Wings $^{\text {ns }}$ & 15.71 & 15.87 & 16.49 & 16.53 & 15.61 & 1.73 \\
\hline Heartns & 2.45 & 2.34 & 2.51 & 2.29 & 2.25 & 4.58 \\
\hline Liver $^{\mathrm{L}}$ & 5.60 & 5.78 & 5.25 & 5.21 & 4.96 & 6.13 \\
\hline Gizzard & 4.18 & 4.80 & 5.10 & 5.31 & 5.16 & 9.14 \\
\hline \multicolumn{7}{|c|}{ Relative weight (\%) } \\
\hline Carcass $^{\mathrm{ns}}$ & 72.23 & 70.17 & 70.57 & 69.52 & 70.27 & 1.43 \\
\hline BreastL & 42.20 & 40.86 & 41.06 & 40.20 & 40.31 & 1.95 \\
\hline Back $^{\mathrm{L}}$ & 26.19 & 27.45 & 27.73 & 28.48 & 28.99 & 3.87 \\
\hline Legs $^{\mathrm{L}}$ & 23.14 & 22.23 & 22.56 & 22.61 & 22.26 & 1.82 \\
\hline Wings $^{\text {ns }}$ & 8.32 & 8.49 & 8.42 & 8.52 & 8.21 & 1.54 \\
\hline Heartns & 1.30 & 1.24 & 1.28 & 1.18 & 1.18 & 4.40 \\
\hline Liver $^{\text {ns }}$ & 2.96 & 3.09 & 2.68 & 2.68 & 2.61 & 7.55 \\
\hline GizzardQ & 2.22 & 2.55 & 2.60 & 2.74 & 2.71 & 8.03 \\
\hline
\end{tabular}

Table 3. Live weight at slaughter and absolute and relative weights of carcass, cuts, and edible viscera of quail at 35 days of age fed diets with levels of cassava foliage hay

L Linear effect $(\mathrm{P}<0.05)$; Q Quadratic effect $(\mathrm{P}<0.05)$; ${ }^{\text {ns }}$ not significant $(\mathrm{P}<0.05)$.

The statistical difference observed in the absolute weight of the back must be related to the non-uniformity during the cuts rather than to the effects of levels of inclusion of the tested by-product, since the other cuts were not significantly influenced. Moreover, the difference found in the relative weight of the cuts is possibly associated with the effect of sex, since unsexed quail were used and the choice of birds for slaughter was based on the average weight of the plot. Costa et al. (2007) and Furtado et al. (2011) did not find influences of cassava inclusion in the diets of free-range broilers on their carcass yield. Trompiz et al. (2010), however, evaluated the inclusion of cassava leaf hay in broiler diets and obtained an increase in drumstick yield and no effects on the absolute weight and yields of the other carcass components.

With respect to the edible viscera, the absolute weight of the liver decreased linearly $(\mathrm{P}<0.05)$ by $0.03715 \mathrm{~g} / \mathrm{bird}$ for every $1 \%$ of inclusion of $\mathrm{CFH}$ in the diets, as expressed by the equation:

$$
\hat{\mathrm{Y}}=5,72775-0,03715 \mathrm{X}\left(\mathrm{R}^{2}=0.73\right) .
$$

The absolute and relative weights of the gizzard varied quadratically $(\mathrm{P}<0.05)$, with estimates that the byproduct inclusion levels of $15.38 \%$ and $16.56 \%$, respectively, would provide the greatest development of the organ, according to the following respective equations:

$$
\begin{gathered}
\hat{Y}=4,18164+\begin{array}{c}
0,141743 X-0,00460714 X^{2} \\
\left(R^{2}=0.99\right) \text { and }
\end{array} \\
\hat{Y}=2,24400+\begin{array}{c}
0,0587750 X-0,00177500 X^{2} \\
\left(R^{2}=0.92\right) .
\end{array}
\end{gathered}
$$

The reduction in liver size was likely a result of the increasing amount of oil in the diets containing a higher level of inclusion of $\mathrm{CFH}$, which led to a lower lipogenic activity and consequently lower development of this organ. The increased gizzard size, however, was because of the greater stimulus for abrasion caused by the fibers in the diets with higher inclusion of CFH. As stated by González-Alvarado et al. (2007), fibrous feeds are great simulators that interfere with the development of the gizzard, considering that this stimulus depends on the type of ingredient, the size, and characteristics of the feed particles. 
These results corroborate those obtained by Iheukwumere et al. (2007), who found a reduction in the weight of the liver of broilers which received diets containing cassava leaves. Similarly, Costa et al. (2007) found a linear increase $(\mathrm{P}<0.05)$ in the absolute and relative weights of the gizzard of broilers receiving diets with increasing levels of cassava. Furtado et al. (2011) observed an increase in the relative weight of the liver and in the gizzard weight of free-range broilers that received diets with increasing levels of cassava. Results of the economic analysis of the studied variables are shown in Table 4.
In numerical values, the treatment containing $10 \% \mathrm{CFH}$ was superior to the others for the economic indicators gross margin, relative gross margin, mean rate of return, and relative return index. The treatment containing $20 \%$ of the by-product had a higher gross revenue in relation to the others; however, it was only superior to the treatment with $15 \% \mathrm{CFH}$ for the variables gross margin and relative gross margin, with lower mean rate of return and relative return index among the treatments.

Table 4. Economic analysis of inclusion of cassava foliage hay in diets for meat quail at 35 days of age.

\begin{tabular}{|c|c|c|c|c|c|c|c|c|c|}
\hline \multirow[b]{2}{*}{ Treatment } & \multicolumn{9}{|c|}{ Economic variable $^{1}$} \\
\hline & $\begin{array}{l}\text { LW } \\
\text { (kg) }\end{array}$ & FI (kg) & $\begin{array}{c}\mathrm{PD} \\
(\mathrm{R} \$)\end{array}$ & $\begin{array}{c}\mathrm{FC} \\
(\mathrm{R} \$ / \mathrm{bird})\end{array}$ & $\begin{array}{c}\text { GR } \\
\text { (R\$/bird) }\end{array}$ & $\begin{array}{c}\mathrm{GM} \\
\text { (R\$/bird) }\end{array}$ & $\begin{array}{c}\text { RGM } \\
(\%)\end{array}$ & $\begin{array}{c}\text { MRR } \\
(\%)\end{array}$ & RRI (\%) \\
\hline 0.0 & 0.260 & 0.762 & 1.255 & 0.956 & 2.329 & 1.374 & 100.00 & 143.83 & 100.00 \\
\hline 5.0 & 0.261 & 0.778 & 1.254 & 0.975 & 2.337 & 1.362 & 99.14 & 139.66 & 97.10 \\
\hline 10.0 & 0.265 & 0.771 & 1.253 & 0.966 & 2.370 & 1.403 & 102.15 & 145.19 & 100.94 \\
\hline 15.0 & 0.265 & 0.813 & 1.252 & 1.018 & 2.371 & 1.353 & 98.49 & 132.95 & 92.43 \\
\hline 20.0 & 0.267 & 0.821 & 1.251 & 1.027 & 2.389 & 1.361 & 99.11 & 132.61 & 92.19 \\
\hline
\end{tabular}

${ }_{1}^{1} \mathrm{LW}$ - live weight; FI - feed intake; PD - price of the diets; FC - feeding cost; GR - gross revenue; GM - gross margin; RGM - relative gross margin; MRR - mean rate of return; RRI - relative return index.

Therefore, dietary inclusion of cassava foliage hay is a viable alternative to feed meat quail that can provide an equivalent or even superior return as compared with conventional feeds.

\section{CONCLUSIONS}

Inclusion of up to $10 \%$ cassava foliage hay is recommended in diets for quail in the period of 1 to 35 days of age.

\section{REFERENCES}

ADEYEMI, O. A.; ADEKOYA, J.A.; SOBAYO, R.A. Performance of broiler chickens fed diets containing cassava leaf: blood meal mix as replacement for soybean meal. Revista Científica UDO Agrícola, v. 12, n. 1 , p. 213-220, 2012

ARRUDA, A.M.V. et al. Avaliação nutricional do feno de maniva de mandioca com aves caipiras. Acta Veterinaria Brasilica, v.6, n.3, p. 204-210, 2012.

BUFFINGTON, D.E.; COLLAZO-AROCHO, A.; CANTON, G.H.; PITT, D. Black globe-humidity index (BGHI) as comfort equation for dairy cows. Transaction of the American Society of Agricultural Engineering, v. 24, p. 711-714, 1981.

CENI, G. C. et al. Avaliação de componentes nutricionais de cultivares de mandioca (manihot esculenta crantz). Alimentos e nutrição. Araraquara, v. 20, n. 1, p. 107-111, 2009.

COSTA, F. G. P. et al. Avaliação do feno de maniçoba (Manihot pseudoglaziovii Paz \& Hoffman) na alimentação de aves caipiras. Revista Caatinga. Mossoró, v. 20, n. 3, p. 42-48, 2007.

CUNHA, F. S. A. Avaliação da mandioca (Manihot esculenta Crantz) e subprodutos na alimentação de codornas (Coturnix japonica). 2009. 99 f. Monografia (Doutorado em Zootecnia) - Universidade Federal Rural de Pernambuco, Recife, 2009.
ERUVBETINE D. et al. Cassava (Manihot esculenta) leaf and tuber concentrate indiets for broiler chickens. Bioresource Technology, v. 86 , n. 3, p. 277-281, 2003.

FURTADO, D. A. et al. Desempenho de frangos alimentados com feno de maniçoba no semiárido paraibano. Revista Brasileira de Ciências Agrárias, v. 6, n. 4, p. 722-728, 2011.

GONZÁLEZ-ALVARADO, J. M. et al. Effect of type of cereal, heat processing of the cereal, and inclusion of fiber in the diet on productive performance and digestive traits of broilers. Poultry Science, v. 86, p. 1705-1715, 2007.

GUEDES, P. L. C. et al. Produção de forragem de mandioca para alimentação de bovinos leiteiros no agreste paraibano. Tecnologia e Ciência Agropecuária. João Pessoa, v. 1, n. 2, p. 53-59, 2007.

IHEUKWUMERE, F. C. et al. Growth, Blood Chemistry and Carcass Yield of Broilers Fed Cassava Leaf Meal (Manihot esculenta Crantz). International Journal of Poultry Science, v. 6, n. 8 p. 555-559, 2007.

LANA, G. R. Q. Avicultura. Ed. Rural. Recife: UFRPE, 2000. 268 p.

MIRANDA, L. F.; PEREIRA, E. S.; RODRIGUEZ, N. M. et al. Avaliação da composição protéica e aminoacídica de forrageiras tropicais. Revista Caatinga, v.21, n.1, p.36-42, 2008.

NATIONAL RESEARCH COUNCIL - NRC. Nutrient requirements of poultry. 9.ed. Washington: National Academy of Sciences, 1994. p. 4445.

R Developmente Core Team (2014). R: A Language and Environment for Statistical Computing. R Foundation for Statistical Computing, Vienna, Austria. Disponível em: <http://www.R-project.org>. Acesso em: 08 set. 2014 .

SILVA, H. O.; FONSECA, R. A.; GUEDES FILHO, R. S. G. Características produtivas e digestibilidade da farinha de folhas de mandioca em dietas de frangos de corte com e sem adição de enzimas. Revista Brasileira de Zootecnia. Brasília, v. 29, n. 3, p 823-829, 2000.

SILVA, J. A. O. et al. Inclusão do feno da parte aérea da mandioca em rações para codornas japonesas em fase de postura sobre o 
desempenho zootécnico. In: VII CONGRESSO NORDESTINO DE PRODUÇÃO ANIMAL - CNPA 2012. Maceió: Anais... Maceió - Al, 2012.

SILVA, J. H. V.; FILHO, J. J.; COSTA, F. G. P. et al. Exigências nutricionais de codornas. In: XXI CONGRESSO BRASILEIRO DE ZOOTECNIA - Zootec 2011. Maceió: Anais... Maceió - Al, 2011.

SOUZA, A. S. et al. Valor nutricional de frações da parte aérea de quatro variedades de mandioca. Revista Brasileira de Saúde e Produção Animal. Salvador, v. 12, n. 2, p. 441-455, 2011.

TROMPIZ, J. et al. Dietas con follaje de yuca y su efecto sobre las características al sacrificio y rendimiento en canal y en cortes de pollos de engorde. Revista Científica da Faculdade de Ciências Veterinárias - Universidade del Zulia, v. 20, n. 2, p. 293-299, 2010.

TROMPIZ, J. et al. Efecto de raciones con harina de folhage de yuca sobre el comportamiento productivo en pollos de engorda. Revista Científica da Faculdade de Ciências Veterinárias - Universidade del Zulia, v. 17, n. 2, p. 143 - 149, 2007. 